\title{
Defective Insulin Response of Cyclic Adenosine Monophosphate-dependent Protein Kinase in Insulin-resistant Humans
}

Yasuo Kida, Bulangu L. Nyomba, Clifton Bogardus, and David M. Mott

Clinical Diabetes and Nutrition Section, National Institute of Diabetes and Digestive and Kidney Diseases, National Institutes of Health, Phoenix, Arizona 85016

\begin{abstract}
Insulin-stimulated glycogen synthase activity in human muscle correlates with insulin-mediated glucose disposal and is reduced in insulin-resistant subjects. Inhibition of the cyclic AMP-dependent protein kinase (A-kinase) is considered as a possible mechanism of insulin action for glycogen synthase activation. In this study, we investigated the time course of insulin action on human muscle A-kinase activity during a 2 -h insulin infusion in 13 insulin-sensitive (group $S$ ) and 7 insulin-resistant subjects (group R). Muscle biopsies were obtained from quadriceps femoris muscle at times $0,10,20,40$, and $120 \mathrm{~min}$.

Insulin infusion resulted in significant inhibition of A-kinase activity at 20 and/or $40 \mathrm{~min}$ using $0.2,0.6$, and $1.0 \mu \mathrm{M}$ cyclic AMP in group S. A-kinase activities both before and after insulin administration were lower in group $S$ than in group $\mathrm{R}$ using $0.6 \mu \mathrm{M}$ cyclic AMP. The decrease in apparent affinity for cyclic AMP during insulin infusion was larger for group $S$ compared with group $\mathbf{R}$. Glycogen synthase activity increased significantly after insulin infusion in both groups and was higher in group $\mathbf{S}$ compared with group $\mathbf{R}$.

The data suggest that a defective response of A-kinase to insulin in insulin-resistant subjects could contribute to their reduced insulin stimulation of skeletal muscle glycogen synthase. (J. Clin. Invest. 1991. 87:673-679.) Key words: glycogen synthase $\bullet$ protein phosphorylation $\bullet$ muscle
\end{abstract}

\section{Introduction}

Glucose storage via glycogen synthesis in skeletal muscle is a major determinant of insulin-mediated glucose disposal (1-3). A rate-limiting enzyme in glycogen synthesis is glycogen synthase which is regulated by both covalent phosphorylation-dephosphorylation and allosteric modifications (4-8). Phosphorylation (inactivation) of glycogen synthase is catalyzed by several different protein kinases acting on different phosphorylation sites (9-11), while the reverse reaction (activation) is catalyzed by protein phosphatases $(12,13)$.

Insulin administration results in a rapid increase in the percentage of synthase in the I (G6P-independent) form and stimulates glycogen synthesis in both animal and human tissues $(1,3$,

Address correspondence and reprint requests to Dr. David M. Mott, National Institutes of Health, 4212 North 16th Street, Room 541, Phoenix, AZ 85016.

Received for publication 19 January 1990 and in revised form 27 September 1990.

The Journal of Clinical Investigation, Inc.

Volume 87, February 1991, 673-679
14-20). However, the mechanism by which insulin stimulates a conversion of synthase D to $I$ is as yet unclear in human skeletal muscle. It could result from a decrease in protein kinase activity and/or an increase in synthase phosphatase activity $(5-7,11,12,20-22)$. cAMP-dependent protein kinase (Akinase $)^{1}$ is regulated hormonally and plays a central role in the regulation of glycogen metabolism $(23,24)$. Previous data have demonstrated that insulin stimulation of glycogen synthase is associated with a decrease in endogenous protein phosphorylation or inhibition of A-kinase in animals $(11,21,25,26)$. Our recent data also demonstrated an insulin-mediated inhibition of A-kinase activity in human skeletal muscle after a hyperinsulinemic clamp (22). However, the possibility that abnormal insulin regulation of A-kinase could contribute to abnormal insulin activation of glycogen synthase in insulin-resistant man has not been studied.

Here, we characterize the A-kinase assay using Kemptide as a substrate and investigate the time course for insulin regulation of A-kinase and glycogen synthase during a hyperinsulinemic, euglycemic clamp. Results are compared for human skeletal muscle from insulin-sensitive and -resistant subjects.

\section{Methods}

Subjects. 13 insulin-sensitive subjects (group S, 8 Caucasians and 5 Pima Indians) and 7 insulin-resistant Pima Indians (group R) participated in this study. These subjects were selected to have an insulin-mediated glucose disposal rate in $\mathrm{mg} / \mathrm{kg}$ fat free mass $\cdot \min (M)$, which was significantly lower in group $\mathrm{R}$ than in group $\mathrm{S}(P<0.001)$. Subjects with $M$ values $<8$ were considered to be insulin-resistant. Pima Indians and Caucasians in group $S$ had similar activity and insulin response for both glycogen synthase and A-kinase. Sex, age, body weight, percent body fat, $M$, fasting plasma glucose, and insulin levels are listed in Table I. Body weight $(P<0.01)$, percent body fat $(P<0.001)$, and fasting plasma insulin $(P<0.001)$ were significantly higher in group $R$ than in group $S$.

Informed consent was obtained and fitness for the study was determined by medical history, physical examination, electrocardiography, and routine blood biochemical and hematological testing. None of the subjects was taking any medication. After consuming a weight maintaining diet ( $20 \%$ protein, $50 \%$ carbohydrate, and $30 \%$ fat) for at least 2 $\mathrm{d}$, each subject had a 75-g oral glucose tolerance test. None of the subjects had diabetes mellitus but 3 subjects in group $R$ had impaired glucose tolerance according to the criteria established by the National Diabetes Data Group (27). After at least $3 \mathrm{~d}$ on a weight maintenance diet, a hyperinsulinemic, euglycemic clamp was performed. Body fat was estimated by underwater weighing with simultaneous measurement of residual lung volume (28).

1. Abbreviations used in this paper: A-kinase, cAMP-dependent protein kinase; G6P, glucose-6-phosphate; $K_{\mathrm{a}}$, apparent activation constant; $\mathrm{KF}$, potassium fluoride; $\mathbf{M}$, insulin-mediated glucose disposal rate; group $\mathrm{R}$ or $\mathrm{S}$, insulin resistant or sensitive subjects; RMAV, repeated measures analysis of variance. 
Table I. Patient Characteristics

\begin{tabular}{|c|c|c|c|c|c|c|c|c|}
\hline No. & Sex & Age & Race & Body weight & Body fat & $\mathbf{M}$ & FPG & FIRI \\
\hline & & $y r$ & & $\mathrm{~kg}$ & $\%$ & $\mathrm{mg} / \mathrm{kg}$ fat free mass per min & $m g / d l$ & $\mu U / m l$ \\
\hline \multicolumn{9}{|l|}{ Group S } \\
\hline 1 & $\mathrm{~m}$ & 27 & C & 68 & 15 & 11.6 & 90 & 7 \\
\hline 2 & $\mathrm{~m}$ & 34 & $\mathrm{C}$ & 75 & 11 & 11.6 & 100 & 5 \\
\hline 3 & $\mathrm{f}$ & 28 & $\mathrm{C}$ & 56 & 20 & 9.3 & 89 & 4 \\
\hline 4 & $\mathrm{~m}$ & 21 & $\mathrm{C}$ & 82 & 18 & 13.4 & 88 & 4 \\
\hline 5 & $\mathrm{~m}$ & 22 & $\mathrm{C}$ & 74 & 8 & 10.3 & 89 & 5 \\
\hline 6 & $\mathrm{~m}$ & 23 & $\mathrm{C}$ & 84 & 15 & 11.7 & 88 & 14 \\
\hline 7 & $\mathrm{~m}$ & 21 & $\mathrm{C}$ & 66 & 11 & 13.5 & 77 & 3 \\
\hline 8 & $\mathrm{~m}$ & 35 & $\mathrm{C}$ & 99 & 20 & 11.8 & 90 & 4 \\
\hline 9 & $\mathrm{~m}$ & 26 & $\mathbf{P}$ & 65 & 22 & 14.2 & 77 & 3 \\
\hline 10 & $\mathrm{~m}$ & 27 & $\mathbf{P}$ & 97 & 33 & 9.2 & 86 & 6 \\
\hline 11 & $\mathrm{~m}$ & 27 & $\mathbf{P}$ & 84 & 24 & 8.7 & 92 & 13 \\
\hline 12 & $\mathrm{~m}$ & 32 & $\mathbf{P}$ & 64 & 17 & 18.7 & 95 & 3 \\
\hline 13 & f & 32 & $\mathbf{P}$ & 94 & 42 & 9.2 & 105 & 23 \\
\hline Mean \pm SE & & $27 \pm 1$ & & $78 \pm 4$ & $20 \pm 3$ & $11.8 \pm 0.8$ & $90 \pm 8$ & $7 \pm 2$ \\
\hline \multicolumn{9}{|l|}{ Group R } \\
\hline 1 & f & 37 & $\mathbf{P}$ & 111 & 47 & 7.5 & 99 & 47 \\
\hline 2 & $\mathrm{~m}$ & 42 & $\mathbf{P}$ & 86 & 30 & 7.5 & 90 & 10 \\
\hline 3 & $\mathrm{~m}$ & 43 & $\mathbf{P}$ & 148 & 42 & 5.3 & 106 & 45 \\
\hline 4 & $\mathrm{~m}$ & 33 & $\mathbf{P}$ & 113 & 34 & 5.9 & 103 & 19 \\
\hline 5 & f & 19 & $\mathbf{P}$ & 123 & 42 & 5.5 & 88 & 37 \\
\hline 6 & $\mathrm{~m}$ & 26 & $P$ & 114 & 36 & 6.7 & 92 & 30 \\
\hline 7 & $\mathrm{~m}$ & 38 & $P$ & 190 & 41 & 6.4 & 92 & 40 \\
\hline Mean \pm SE & & $34 \pm 4$ & & $126 * \pm 14$ & $39^{ \pm} \pm 2$ & $6.4^{\ddagger} \pm 0.4$ & $96 \pm 3$ & $33^{\ddagger} \pm 6$ \\
\hline
\end{tabular}

$m$, male; $f$, female; $C$, Caucasian; $P$, Pima Indian; $M$, insulin-mediated glucose disposal rate; $F P G$, fasting plasma glucose; $F I R I$, fasting plasma insulin. $t$ test: ${ }^{*} P<0.01,{ }^{\ddagger} P<0.001$ between groups.

Hyperinsulinemic, euglycemic clamp. After an overnight fast, a hyperinsulinemic, euglycemic clamp was performed as previously described (20). The clamp was initiated by a primed-continuous high dose insulin infusion $\left(600 \mathrm{mU} / \mathrm{min}\right.$ per $\left.\mathrm{m}^{2}\right)$ for $120 \mathrm{~min}$. After the start of insulin infusion, a variable infusion of $20 \%$ glucose was given as necessary to maintain the plasma glucose concentration at $100 \mathrm{mg} / \mathrm{dl}$ for all subjects.

The plasma insulin concentration was determined before the start of insulin infusion and at $10,20,40,60,80$, and 120 min during the clamp. The plasma glucose was determined before the start of insulin infusion and every 2.5 or $5 \mathrm{~min}$ through the end of the clamp. Insulinstimulated glucose disposal rate $(\mathrm{mg} / \mathrm{kg}$ fat-free mass per $\mathrm{min}$ ) was determined during the period from 80 to $120 \mathrm{~min}$. The steady-state plasma insulin and glucose were $\sim 3,000 \mu \mathrm{U} / \mathrm{ml}$ and $100 \mathrm{mg} / \mathrm{dl}$, respec- tively, in both groups (Table II). Plasma glucose concentrations and insulin concentrations were measured by the glucose oxidase method using a Beckman Instruments, Inc. glucose analyzer (Fullerton, CA) and a radioimmunoassay using a Concept 4 radioassay analyzer (ICN, Inc., Horsham, PA), respectively.

Muscle biopsy. Before the start of insulin infusion (time $=0)$ and at the indicated time points after insulin infusion (Figs. 4-7), percutaneous muscle biopsies were taken from the quadriceps femoris muscle using Bergström needle (Depuy, Phoenix, AZ) as previously described (20). Specimens $(80-120 \mathrm{mg})$ were frozen in liquid nitrogen within $15 \mathrm{~s}$ and stored at $-70^{\circ} \mathrm{C}$. These biopsies were lyophilized, dissected free of blood, fat, and all visible connective tissue, and powdered. The powder was thoroughly mixed and stored at $-70^{\circ} \mathrm{C}$ before analysis.

Enzyme assay. Glycogen synthase activity was determined after

Table II. Plasma Glucose and Insulin Concentrations During Insulin Infusion

\begin{tabular}{|c|c|c|c|c|c|c|c|c|}
\hline Time $(\min )$ & 0 & 10 & 20 & 40 & 60 & 80 & 100 & 120 \\
\hline \multicolumn{9}{|c|}{ Plasma glucose $(\mathrm{mg} / \mathrm{dl})$} \\
\hline Group S & $98 \pm 1$ & $102 \pm 2$ & $96 \pm 3$ & $96 \pm 3$ & $101 \pm 3$ & $102 \pm 2$ & $101 \pm 1$ & $99 \pm 2$ \\
\hline Group R & $99 \pm 1$ & $103 \pm 2$ & $101 \pm 3$ & $102 \pm 1$ & $99 \pm 1$ & $99 \pm 1$ & $100 \pm 1$ & $98 \pm 2$ \\
\hline \multicolumn{9}{|c|}{ Plasma insulin $(\mu U / m l)$} \\
\hline Group S & $7 \pm 2$ & $1672 \pm 130$ & $2076 \pm 187$ & $2407 \pm 204$ & $2586 \pm 203$ & $2820 \pm 220$ & - & $3061 \pm 283$ \\
\hline Group R & $29 \pm 4^{*}$ & $1710 \pm 123$ & $1908 \pm 170$ & $2336 \pm 255$ & $2623 \pm 306$ & $2784 \pm 300$ & - & $3252 \pm 364$ \\
\hline
\end{tabular}

Glucose values are the mean $\pm \mathrm{SE}$ of samples drawn at 2.5 - to 5 -min intervals using 10 - or 20 -min intervals before indicated times. Insulin values are the mean $\pm \mathrm{SE}$ of samples drawn at indicated times. $t$ test: ${ }^{*} P<0.001$ between groups. 
modification of the method of Guinovart (29) and Thomas (30) as previously described (20). Briefly, dry muscle powder was homogenized in a $30 \%$ glycerol, $10 \mathrm{mM}$ EDTA, $50 \mathrm{mM}$ potassium fluoride (KF), pH 7 solution ( $200 \mu \mathrm{l} / \mathrm{mg}$ dry weight), using a Potter-Elvehjem tissue grinder (Radnoti Glass Technology, Inc., Monrovia, CA) at $4^{\circ} \mathrm{C}$. The homogenate was centrifuged at $10,000 \mathrm{~g}$ for $20 \mathrm{~min}$ at $4^{\circ} \mathrm{C}$. The supernatant was diluted with a buffer containing $50 \mathrm{mM}$ Tris, $20 \mathrm{mM}$

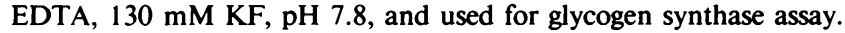
Glycogen synthase activity was assayed at 0.17 and $7.2 \mathrm{mM}$ glucose-6phosphate (G6P) (total glycogen synthase activity). Fractional activity is the ratio of synthase activity measured at 0.17 and $7.2 \mathrm{mM} \mathrm{G6P}$. The activities are expressed as units per gram dry weight $(\mathrm{U} / \mathrm{g})$. One unit equals $1 \mu \mathrm{mol}\left[{ }^{14} \mathrm{C}\right]$ glucose incorporated into glycogen per minute at $30^{\circ} \mathrm{C}$. G6P and uridine diphosphate glucose (UDPG) were purchased from Sigma Chemical Co. (St. Louis, MO) and ${ }^{14} \mathrm{C}$-UDPG from New England Nuclear (Boston, MA). The glycogen synthase assay was linear with time over the range of activity measured and interassay variation was $5 \%$.

Human muscle A-kinase was determined using Kemptide (31) as a substrate and methods from previous publications $(11,22,32)$. Dry muscle powder was homogenized in a buffer $(54 \mu \mathrm{l} / \mathrm{mg}$ dry weight unless otherwise indicated) containing $10 \mathrm{mM}$ Tris- $\mathrm{HCl}, 10 \mathrm{mM}$ EDTA, $100 \mathrm{mM} \mathrm{KF}, \mathrm{pH} 7.8$, using a Potter-Elvehjem tissue grinder. The homogenate was centrifuged at $12,800 \mathrm{~g}$ for $10 \mathrm{~min}$ at $4^{\circ} \mathrm{C}$ and the supernatant was assayed for protein kinase activity in the presence or absence of cAMP. The extract $(18 \mu \mathrm{l})$ was incubated with $102 \mu \mathrm{l}$ of reaction mixture giving a final concentration of $200 \mu \mathrm{M}$ Kemptide (K1127; Sigma Chemical Co.), $0.3 \mathrm{mM}$ gamma-[ $\left.{ }^{32} \mathrm{P}\right] \mathrm{ATP}$ (sp act $=50$ $80 \mathrm{cpm} / \mathrm{pmol}$, NEN Research Products, Boston, MA), $50 \mathrm{mM}$ 2-[Nmorpholino]-ethanesulfonic acid, $8 \mathrm{mM} \mathrm{MgCl}_{2}, \mathrm{pH} 6.5$, in the absence or presence of $0.2,0.6,1$, and $100 \mu \mathrm{M}$ cAMP at $30^{\circ} \mathrm{C}$. The final concentration of $15 \mathrm{mM} \mathrm{KF}$ in the assay should prevent significant hydrolysis of phosphorylated Kemptide by endogenous type-1-protein phosphatase (33). At 0 and $3 \mathrm{~min}, 30-\mu l$ aliquots were spotted on $2 \times 2 \mathrm{~cm}$ phosphocellulose papers (Whatman P81; Whatman International, Limited, Maidstone, England). The papers were washed twice with 150 $\mathrm{mM} \mathrm{H}_{3} \mathrm{PO}_{4}$ and rinsed with $95 \%$ ethanol. Nonspecific phosphorylation of Kemptide without extract during incubation was $<0.01 \%$ of cAMPindependent activity. Protein kinase activity was expressed as ${ }^{32} \mathrm{P}$-incorporation into Kemptide per minute per gram muscle dry weight (nmol ${ }^{32} \mathrm{P} / \mathrm{min} \cdot \mathrm{g}$ ).

${ }^{32} \mathrm{P}$-incorporation into Kemptide using basal or insulin-stimulated samples with or without cAMP was linear up to $5 \mathrm{~min}$. Comparable linearity for subjects from groups $S$ and $R$ (Fig. 1) demonstrated the absence of significant phosphodiesterase activity after insulin infusion and during the 3-min incubation period of the enzyme assay. This was verified by testing the decrease in exogenous $(0.3 \mu \mathrm{M})$ cAMP added to homogenates in the A-kinase assay system at $30^{\circ} \mathrm{C}$. The mean 3-min decrease in cAMP concentration from four biopsies (two obtained before and two after insulin stimulation) was $7.4 \pm 1.4 \%$. Similar results were obtained from group $\mathrm{S}$ and group $\mathrm{R}$ subjects (data not shown). The linear increase of activity with time also indicated the absence of significant changes in free catalytic subunit concentration during the $30^{\circ} \mathrm{C}$ incubation. The interassay variations of cAMP-dependent and -independent activities were 5-10 and 10-15\%, respectively. cAMP-independent activities were $\sim 10 \%$ of maximum activity and were subtracted from activities assayed with cAMP to obtain cAMP-dependent kinase activities shown in Figs. 1, 2, 3, 5B and 6. The apparent activation constant $\left(K_{\mathrm{a}}\right)$ (inversely proportional to apparent affinity) for cAMP activation of protein kinase was determined from individual dose-response curves at $0,0.2,0.6,1.0$, and $100 \mu \mathrm{M}$ cAMP. $K_{\mathrm{a}}$ was determined graphically as the concentration of cAMP required for onehalf maximal stimulation of kinase activity between 0 and $100 \mu \mathrm{M}$ cAMP. Activities of glycogen synthase and A-kinase were $105 \pm 5$ and $89 \pm 3$ percent of values obtained on frozen nonlyophilized samples from the same subjects.

Muscle cAMP concentrations were determined in 14 subjects $(10$ in group S, 4 in group R) using cAMP RIA kit (TRK 432; Amersham

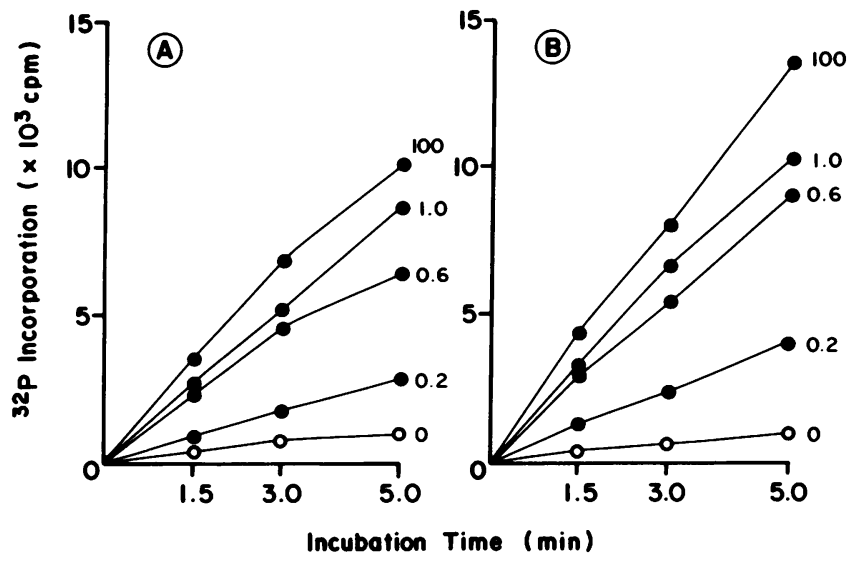

Figure 1. Protein kinase activity with respect to time. Activity was measured at the indicated $\mu \mathrm{M}$ cAMP concentrations. CAMPdependent activity (๑) has been corrected for cAMP-independent activity (O). All results are from a single biopsy after $20 \mathrm{~min}$ of insulin infusion. Each point is the mean of duplicate determinations. $(A)$ Group S subject; $(B)$ group R subject.

Corp., United Kingdom) after $0.5 \mathrm{M}$ perchloric acid extraction. Interassay variation was $5 \%$. The average (range) of dry muscle weight was $23 \%(22-24 \%)$ of wet weight.

Statistics. Data generated from repeated biopsies before and during $120 \mathrm{~min}$ of insulin infusion were analyzed by repeated measures analysis of variance (RMAV) of one grouping factor (i.e., insulin-sensitive versus -resistant) and five "within factors" (time). Significance $(P$ $<0.05$ ) was also analyzed with Student's paired or nonpaired $t$ test. All data were expressed as mean \pm SE unless otherwise indicated.

\section{Results}

A-kinase in human muscle. The relationship between homogenate protein concentration and kinase activity was determined using fasting samples (Fig. 2). The relationship between A-kinase activity and homogenate concentration was not linear and peaked between 36 and $108 \mu \mathrm{l} / \mathrm{mg}$ muscle $(2.1$ to $0.6 \mathrm{mg}$ pro$\mathrm{tein} / \mathrm{ml}$ in assay). With the increase in homogenate concentration from 108 to $12 \mu \mathrm{l} / \mathrm{mg}$, the dose-response curve shifted to the right and the $K_{\mathrm{a}}$ for cAMP increased from 0.33 to $0.62 \mu \mathrm{M}$ (Fig. 3). Based on these observations, muscle powder homogenized with $54 \mu \mathrm{l}$ buffer/mg dry weight was used for analysis of protein kinase activity unless otherwise indicated.

Glycogen synthase activity during insulin infusion. Glyco-

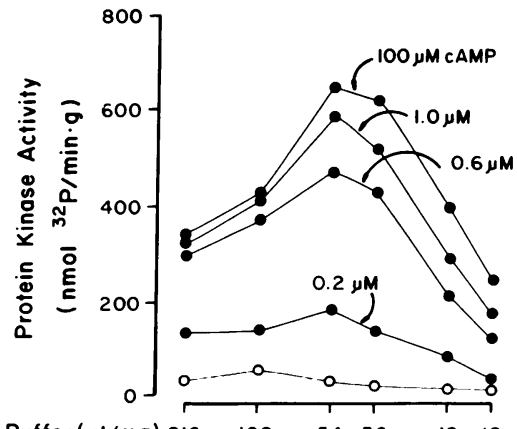

Figure 2. Relationship between homogenate concentration and cAMP-independent $(0)$ or -dependent $(\bullet)$ kinase activity normalized per gram dry muscle. The highest A-kinase activity was obtained using extract homogenized with $54 \mu \mathrm{l} \mathrm{buffer} / \mathrm{mg}$ dry weight $(1.3 \mathrm{mg}$ Buffer $(\mu \mathrm{l} / \mathrm{mg}) 216 \quad 108 \quad 54 \quad 36 \quad 18 \quad 12 \quad$ protein $/ \mathrm{ml}$ in assay). All results are from a single fasting muscle biopsy. Each point is the mean of duplicate determinations. 


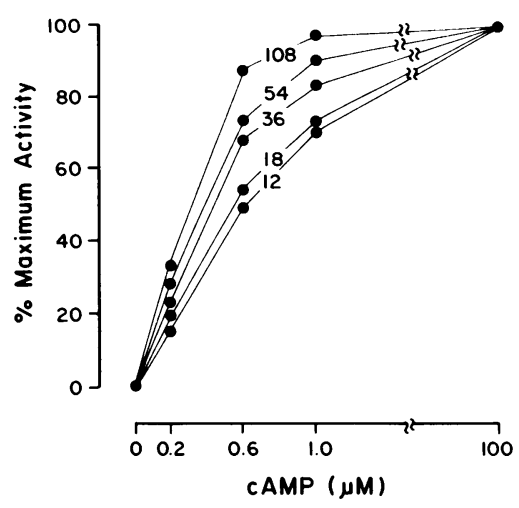

human muscle biopsy. Each point is the mean of duplicate determinations.

gen synthase total activity and its fractional activity during insulin infusion are shown in Fig. 4. Using RMAV, there was no significant change of total activity with time or difference in total activity between the two groups (Fig. $4 \mathrm{~A}$ ). Before insulin infusion, there was no significant difference in glycogen synthase fractional activity between groups (Fig. $4 \mathrm{~B}$ ). Fractional activity at 10 and $120 \mathrm{~min}$ were, however, significantly higher $(t$ test) in group $\mathrm{S}$ compared with group $\mathrm{R}(P<0.05)$. Fractional activity was also significantly higher by RMAV for group $\mathrm{S}$ during the time course for insulin infusion $(P<0.05)$. In addition, fractional activity increased significantly with time (RMAV), but this change was not significantly different between groups. Caucasian and Pima subjects in group $S$ had similar changes in fractional activity after insulin infusion (Table III).

Insulin-mediated change of kinase activity and cAMP. There was no significant change of cAMP-independent Kemptide kinase and maximum (100 $\mu \mathrm{M}$ cAMP) dependent Kemptide kinase activity in either group during the insulin infusion (Fig. $5 \mathrm{~A}$ and $5 \mathrm{~B}$ ). Although there was no significant difference in maximum activity between the two groups by RMAV, the mean maximum activities at each time point in group $R$ were about $10 \%$ higher than in group $S$ (Fig. $5 \mathrm{~B}$ ).

In group $S$ but not in group $\mathrm{R}$, only 0.2 and $0.6 \mu \mathrm{M}$ cAMPdependent kinase activities decreased significantly $(P<0.05$ by RMAV) during insulin infusion (Fig. 6). The activities tested between 0 and 120 minutes by RMAV were significantly higher in group $\mathrm{R}$ compared with group $\mathrm{S}$ at $0.2,0.6$, and 1.0 $\mu \mathrm{M}$ cAMP $(P<0.005,0.001$, and 0.05$)$. The greatest difference in A-kinase activity between the two groups appears to occur after $20 \mathrm{~min}$ of insulin infusion where at $0.6 \mu \mathrm{M}$ cAMP the $\mathrm{S}$ group has only $70 \%$ of the activity measured in the $R$ group.

The $K_{\mathrm{a}}$ of A-kinase for cAMP is shown in Fig. 7. The $K_{\mathrm{a}}$

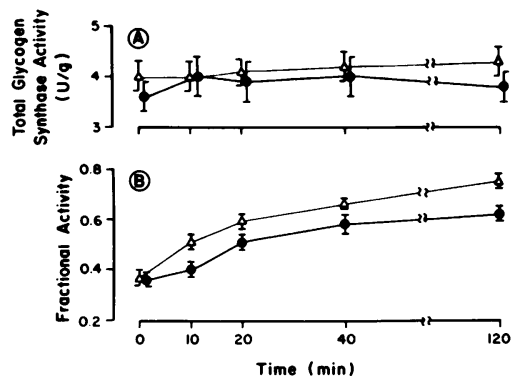

Figure 4. Total glycogen synthase activity $(A)$ and glycogen synthase fractional activity $(B)$ in group $S(\Delta)$ and group $R(\bullet)$ during insulin infusion.
Table III. Insulin-mediated Change in Glycogen Synthase Fractional Activity by Race

\begin{tabular}{clll} 
& \multicolumn{2}{c}{ Group S } & Group R \\
\cline { 2 - 3 } Insulin infusion & Caucasian & Pima Indian & Pima Indian \\
\hline $\min$ & & & \\
10 & $0.13 \pm 0.01^{*}$ & $0.15 \pm 0.01^{*}$ & $0.04 \pm 0.01$ \\
20 & $0.22 \pm 0.04$ & $0.22 \pm 0.02$ & $0.14 \pm 0.02$ \\
40 & $0.28 \pm 0.04$ & $0.31 \pm 0.03$ & $0.22 \pm 0.04$ \\
120 & $0.40 \pm 0.02^{*}$ & $0.36 \pm 0.02$ & $0.26 \pm 0.02$
\end{tabular}

$t$ test: ${ }^{*} P<0.05$ vs. group $\mathrm{R}$.

increased with time in both groups but was significantly higher $(P<0.001$ by RMAV) in group $S$ compared with group $\mathrm{R}$. The change in $K_{\mathrm{a}}$ with insulin infusion was significantly different comparing the two groups $(P<0.05)$. In group $\mathrm{R}, K_{\mathrm{a}}$ did not increase significantly (paired $t$ test) until $40 \mathrm{~min}(P<0.05)$ compared with the significant rise for $K_{\mathrm{a}}$ in group $\mathrm{S}$ at all time points $(P<0.05$ at 10 and $120 \mathrm{~min}, P<0.001$ at 20 and 40 min). There was no significant relationship between body fat and $K_{\mathrm{a}}$ in group $\mathrm{S}$ after insulin infusion. The A-kinase $K_{\mathrm{a}}$ values were similar for Pima and Caucasian subjects in group S (Table IV). When these studies were repeated on 6 subjects in group $S$ and 5 subjects in group $\mathrm{R}$ using $18 \mu \mathrm{l} / \mathrm{mg}$ tissue by weight in the homogenate, no significant changes in $K_{\mathrm{a}}$ were observed after insulin infusion (data not shown).

Muscle cAMP concentrations were measured over the time course for insulin infusion. There were no significant changes with time of insulin infusion or between groups (data not shown).

\section{Discussion}

We have reported a positive correlation between insulin-stimulated glucose disposal rate and insulin-stimulated skeletal muscle glycogen synthase activity in vivo in man and suggested the regulation of glycogen synthase may contribute to the reduced glucose disposal associated with insulin resistance in Pima Indians $(1,3)$. A similar conclusion was reached in an in vivo study of normal glucose tolerant Caucasians (34).

Glycogen synthase data in this study confirmed the association of impaired activation of insulin-stimulated glycogen synthase with insulin resistance in man. We assayed the active form of glycogen synthase under physiological concentrations $(0.17 \mathrm{mM})$ of G6P in an effort to more closely approximate in

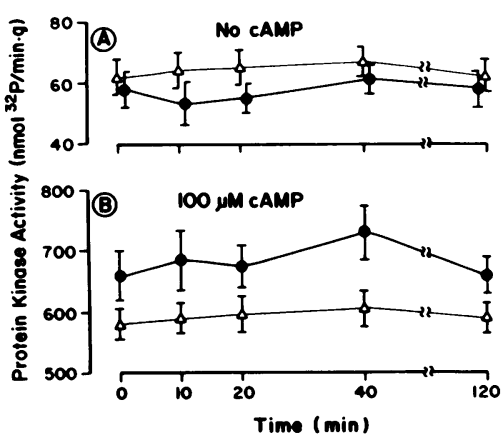

Figure 5. cAMPindependent kinase activity $(A)$ and maximum $(100 \mu \mathrm{M}$ cAMP) dependent kinase activity $(B)$ during insulin infusion. Symbols are the same as in Fig. 4. 


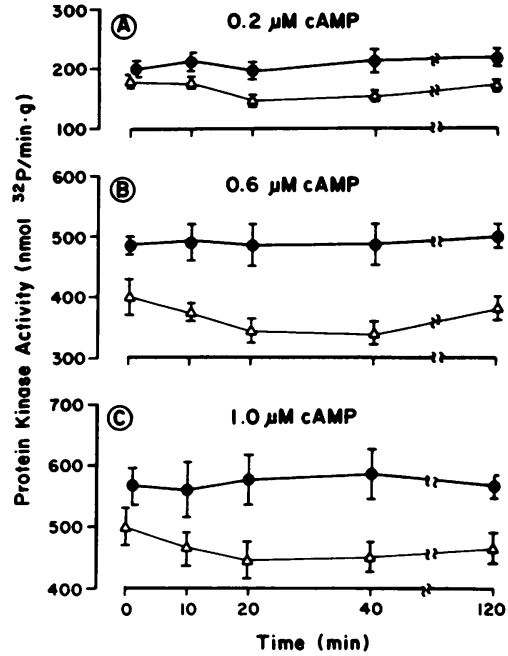

Table IV. Effect of Insulin on A-kinase $K_{a}$ by Race

\begin{tabular}{clll}
\hline & \multicolumn{2}{c}{ Group S } & Group R \\
\cline { 2 - 3 } Insulin infusion & Caucasian & Pima Indian & Pima Indian \\
\hline $\min$ & & & \\
0 & $0.41 \pm 0.02$ & $0.41 \pm 0.03$ & $0.38 \pm 0.02$ \\
10 & $0.45 \pm 0.01^{\ddagger}$ & $0.43 \pm 0.03$ & $0.38 \pm 0.02$ \\
20 & $0.52 \pm 0.02^{\ddagger}$ & $0.49 \pm 0.02^{\ddagger}$ & $0.39 \pm 0.02$ \\
40 & $0.54 \pm 0.02^{\ddagger}$ & $0.49 \pm 0.03$ & $0.43 \pm 0.03$ \\
120 & $0.45 \pm 0.02^{\ddagger}$ & $0.44 \pm 0.02^{*}$ & $0.37 \pm 0.02$
\end{tabular}

dependent kinase activities during insulin infusion assayed in the presence of $0.2(A), 0.6$ $(B)$, and $1 \mu \mathrm{M}(C)$ cAMP. Symbols are the same as in Fig. 4.

vivo activity in skeletal muscle. We used fractional activity as a marker of glycogen synthase activation. After insulin infusion, the fractional activity was significantly higher for group $\mathrm{S}$. The 120 -min activity was $21 \%$ higher in group S. Using RMAV, an increase of total glycogen synthase activity could not be verified in either group. We have previously reported that increased glucose flux into human muscle at constant insulin concentration fails to stimulate glycogen synthase activity (35). This study demonstrates that muscle glycogen synthase is not regulated by changes in glucose transport. The reduced stimulation of glycogen synthase activity in insulin-resistant subjects is also not a function of increased muscle glycogen (4). Fasting muscle glycogen was either similar (1) or reduced (36) in two studies of insulin-resistant subjects. Insulin-resistant subjects also have a significantly smaller increase in muscle glycogen following insulin infusion $(36,37)$.

Glycogen synthase activity is regulated by both noncovalent, allosteric interaction, and covalent phosphorylation/dephosphorylation (5-8). Phosphorylation states of several specific sites in the glycogen synthase molecule alter its activity $(9$, 10). It is well known that insulin is a potent activator of glycogen synthase in liver, fat, and muscle, but the sequence of events leading to insulin-stimulated glycogenesis is not clear in humans. Inhibition of phosphorylation by inactivation of protein kinases $(10,11,21,22,25)$ and/or stimulation of dephosphorylation by protein phosphatase activation $(12,17,19,20)$ have been demonstrated as mechanisms of insulin action.

Recent literature has demonstrated inhibition of the A-ki-

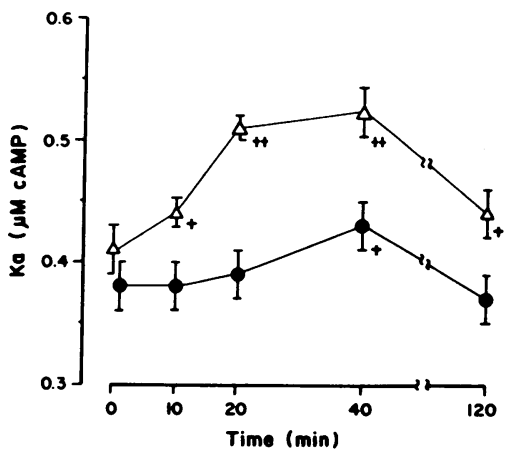

Figure 7. $\mathrm{K}_{\mathrm{a}}$ for cAMP during insulin infusion. Each point represents the mean \pm SE of $K$ values determined from individual doseresponse plots for each subject in groups $S$ and $R$. Symbols are the same as in Fig. 4. Paired $t$ test: ${ }^{+} P<0.05,{ }^{++} P$ $<0.001$ versus $0 \mathrm{~min}$. $t$ test: ${ }^{*} P<0.05,{ }^{\ddagger} P<0.01$ vs. group $\mathrm{R}$

nase in insulin-treated animals $(11,21,26)$. This kinase phosphorylates glycogen synthase on sites $1 \mathrm{a}, 1 \mathrm{~b}$, and 2 , and to a lesser extent sites on 3 and $4(10,38,39)$, resulting in inactivation of glycogen synthase. In addition, A-kinase phosphorylates and activates inhibitor 1 which inhibits protein phosphatase type $1(40,41)$. A-kinase also phosphorylates the G-subunit of protein phosphatase type 1, which promotes translocation of the phosphatase from glycogen particles to the cytosol and may lead to phosphatase inactivation by inhibitor1 (42). Therefore, inhibition of A-kinase in response to insulin could contribute to the activation of glycogen synthase. In human muscle, Okubo et al. (22) used histone type $2 \mathrm{~A}$ as a substrate and demonstrated insulin inhibition of skeletal muscle A-kinase activity at the end of a 200-min hyperinsulinemic clamp. However, the time course for insulin inhibition of Akinase was not determined. In addition, the kinase activity was not characterized in subjects with reduced insulin-mediated glucose disposal. The purpose of this study is to further characterize the assay of A-kinase using human skeletal muscle and to investigate the time course of A-kinase activity during insulin infusion in insulin-sensitive and -resistant subjects.

Preliminary data (not shown) demonstrated that both cAMP-dependent and -independent kinase activities using Kemptide were $\sim$ 4-6 times higher than activities using histone type $2 \mathrm{~A}$ as a substrate. The relationship between A-kinase activity and extract protein concentration is nonlinear (Fig. 2). Similar observations using rat muscle were reported by Oron et al. (26) and Walkenbach et al. (11). Dilution increases the apparent affinity for cAMP (Fig. 3) at the same time that maximum A-kinase activity (100 $\mu \mathrm{M}$ cAMP in Fig. 2$)$ is increasing. These two parameters of A-kinase diverge, however, above 54 $\mu \mathrm{l} / \mathrm{mg}$ dry weight where maximum activity decreases but apparent affinity continues to increase. These biphasic effects of homogenate concentration on enzyme activity may reflect dilution of a family of mediators (activators and inhibitors of Akinase) which have been previously reported in rat skeletal muscle $(43,44)$.

Muscle cAMP concentrations in this study averaged $3.1 \pm 0.6 \mathrm{nmol} / \mathrm{g}$ dry weight $(0.72 \pm 0.14 \mu \mathrm{mol} / \mathrm{kg}$ wet weight $)$ and are similar to previously reported values in resting human muscle (45). Intracellular cAMP concentration was estimated as $\sim 0.90 \pm 0.18 \mu \mathrm{M}$. Because intracellular fluid is diluted $\sim 83$ times in the assay, endogenous cAMP concentration during the reaction would be estimated at $0.01 \mu \mathrm{M}$. Effects of endogenous cAMP on activation of A-kinase during the assay would be negligible. 
The activity measured in the absence of cAMP in Fig. 5 is the result of free catalytic subunit from A-kinase as well as other kinase activities which can phosphorylate Kemptide. Comparison of this activity with the maximum cAMP-dependent activity at $100 \mu \mathrm{M}$ cAMP suggests that, at most, the A-kinase holenzyme is $\sim 10 \%$ dissociated with no significant change produced by $2 \mathrm{~h}$ of insulin infusion. This low activity and presumed low level of cAMP binding (46) is similar in both groups and is ideal for an in vitro estimation of the response of the holenzyme to cAMP in the two groups. The assumption that this low ratio represents a high degree of association between regulatory and catalytic subunits in vivo, however, may be incorrect. It is also possible that during homogenization and assay, this low ratio resulted from a rapid reassociation of catalytic subunit with the regulatory subunit which may have been largely unbound in vivo. Skeletal muscle in rat has been reported to contain two types of regulatory subunit, which have been characterized in adipocytes and heart muscle as having differing stabilities toward subunit reassociation during homogenization (47). Although homogenization conditions have been reported which minimize these changes in subunit association and enzyme activity $(48,49)$, no completely satisfactory system has been reported (50). It is therefore possible that even though no activity differences were observed between groups in the absence of cAMP (Fig. $5 \mathrm{~A}$ ), the in vivo concentrations of free catalytic subunit could be different between groups and could change with insulin infusion.

Fig. 6 shows that group $\mathrm{S}$ has significant changes of A-kinase activities with time of insulin infusion using physiological concentration of cAMP. Differences of the kinase activity between the two groups were most remarkable at $0.6 \mu \mathrm{M}$ cAMP (Fig. 6 B). The data in Fig. 7 demonstrates a significant difference in $K_{\mathrm{a}}$ for cAMP after insulin infusion in the two groups. In group $\mathrm{S}$, reduced affinity for cAMP during $120 \mathrm{~min}$ of insulin infusion, without a change in maximum activity, appears to explain the reduced activity of A-kinase measured at physiologic cAMP concentrations. Several authors have demonstrated that insulin-mediated inhibition of A-kinase is associated with reduced cAMP binding to the regulatory subunit of A-kinase $(51,52)$. On the other hand, in group $\mathrm{R}, K_{\mathrm{a}}$ increased significantly at $40 \mathrm{~min}$ with a concomitant increase in maximum activity (Fig. 5). The net result was no change of A-kinase activity at $40 \mathrm{~min}$. The physiological significance of these changes in $K_{\mathrm{a}}$ and maximum activities is not clear. An increase in the homogenate concentration to $18 \mu \mathrm{l} / \mathrm{mg}$ tissue dry weight removed the insulin-mediated increase in $K_{\mathrm{a}}$ in group $\mathrm{S}$ subjects. Although the mechanism involved here is not known, a similar result has been reported using rat diaphragm muscle (11). The increase in $K_{\mathrm{a}}$ (apparent decrease in enzyme affinity for (AMP) is a transient phenomena for both groups. In contrast is the continuous increase in glycogen synthase activity observed over the 120-min insulin infusion. These different temporal profiles emphasize that mechanisms in addition to the change in A-kinase $K_{\mathrm{a}}$ exist for insulin activation of glycogen synthase. A similar conclusion was reached in studies of insulin stimulation of glycogen synthase phosphatase in human muscle (20). Here phosphatase stimulation peaked at 10 min while glycogen synthase activity continued to increase for $120 \mathrm{~min}$. Together these studies on the time course for insulin regulation of human muscle kinase and phosphatase activities suggest that stimulation of glycogen synthase during euglycemic insulin infusion in man is a composite of continuous change in both kinase and phosphatase activities. Insulin stimulation of glycogen synthase kinase- 3 has recently been reported (53). Although stimulation of this enzyme could directly inactivate glycogen synthase (54), this kinase also phosphorylates inhibitor- 2 which results in activation of the type- 1 protein phosphatase complex or $\mathrm{Fc} \cdot \mathrm{M}(55)$. Insulin regulation of glycogen synthase kinase- 3 may also, therefore, contribute to the dephosphorylation and activation of glycogen synthase observed here.

Insulin has been shown to produce compounds that mediate its action (56-58). A low molecular weight peptide mediator has been purified and identified as an A-kinase inhibitor (59). The mediator binds to A-kinase holoenzyme which leads to lower CAMP binding and reduced release of active catalytic subunit (57). In this study, a significant increase of the $K_{\mathrm{a}}$ for cAMP was observed during insulin infusion in insulin-sensitive subjects. The fact that a shift to lower apparent affinity for cAMP is a result of both increased homogenate concentration (Fig. 3) and of insulin action (Fig. 7) raises the possibility that the same regulator being concentrated in the first experiment is being increased by insulin in the second experiment. The reduced insulin-mediated inhibition of A-kinase activities in the $\mathrm{R}$ group at subsaturating $(0.6 \mu \mathrm{M})$ cAMP concentration (Fig. 6) may be caused by the increased apparent affinity for cAMP which is secondary to reduced insulin mediator concentrations. It is also possible that the observed low values for $K_{\mathrm{a}}$ in group $\mathrm{R}$ are the result of a different composition of types I and II regulatory subunit which bind the cAMP with different affinities (47).

This is the first report that demonstrates reduced insulin action to inhibit A-kinase activities in skeletal muscle from insulin-resistant man. The defective response of A-kinase to insulin may in part explain the diminished insulin-stimulated glycogen synthase activation in subjects with reduced insulinmediated glucose disposal.

\section{Acknowledgments}

We thank the nursing staff, the dietary staff, and the technical staff for their professional assistance. We are also indebted to Susan Elson and Charlesetta Lincoln for their secretarial work. We wish to thank Karen Stone for her technical assistance on the enzyme assays. Most of all, we are grateful to the volunteers for their cooperation during the studies.

\section{References}

1. Bogardus, C., S. Lillioja, K. Stone, and D. M. Mott. 1984. Correlation between muscle glycogen synthase activity and in vivo insulin action in man. $J$. Clin. Invest. 73:1185-1190.

2. Lillioja, S., D. M. Mott, J. K. Zawadzki, A. A. Young, W. G. Abbott, and C. Bogardus. 1986. Glucose storage is a major determinant of in vivo "insulin resistance" in subjects with normal glucose tolerance. J. Clin. Endocrinol. Metab. 62:922-927.

3. Young, A. A., C. Bogardus, K. Stone, and D. M. Mott. 1988. Insulin response of components of whole-body and muscle carbohydrate metabolism in humans. Am. J. Physiol. 254:E231-E236.

4. Danforth, W. H. 1965. Glycogen synthase activity in skeletal muscle: interconversion of two forms and control of glycogen synthesis. J. Biol. Chem. 2:588593.

5. Cohen, P. 1983. Protein phosphorylation and the control of glycogen metabolism in skeletal muscle. Philos. Trans. R. Soc. Lond. B. Biol. Sci. B302:13-25.

6. Cohen, P. 1986. Muscle glycogen synthase. In The Enzymes. Vol 17. P. D. Boyer and E. G. Krebs, editors. Academic Press, Inc., Orlando, FL. 461-497.

7. Stalmans, W., M. Bollen, and L. Mvumbi. 1987. Control of glycogen synthesis in health and disease. Diabetes Metab. Rev. 3:127-161.

8. Roach, P. J., and J. Larner. 1976. Rabbit skeletal muscle glycogen synthase. II. Enzyme phosphorylation state and effector concentrations as interacting control parameters. J. Biol. Chem. 251:1920-1925. 
9. Parker, P. J., F. B. Caudwell, and P. Cohen. 1983. Glycogen synthase from rabbit skeletal muscle: effect of insulin on the state of phosphorylation of seven phosphoserine residues in vivo. Eur. J. Biochem. 130:227-234.

10. Sheorain, V. S., H. Juhl, M. Bass, and T. R. Soderling. 1983. Effects of epinephrine, diabetes, and insulin on rabbit skeletal muscle glycogen synthase. $J$. Biol. Chem. 259:7024-7030.

11. Walkenbach, R. J., R. Hazen, and J. Larner. 1978. Reversible inhibition of cyclic AMP-dependent protein kinase by insulin. Mol. Cell. Biochem. 19:3141.

12. Ingebritsen, T. S., and P. Cohen. 1983. Protein phosphatase: properties and role in cellular regulation. Science (Wash. DC). 221:331-338.

13. Ballou, L. M., and E. H. Fischer. 1986. Phosphoprotein phosphatases. In The Enzymes. Vol 17. P. D. Boyer and E. G. Krebs, editors. Academic Press, Inc., Orlando, FL. 311-361.

14. Okubo, M., C. Bogardus, S. Lillioja, and D. M. Mott. 1988. Glucose-6phosphate stimulation of human muscle glycogen synthase phosphatase. Metabolism. 37:1171-1176.

15. Freymond, D., C. Bogardus, M. Okubo, K. Stone, and D. M. Mott. 1988. Impaired insulin-stimulated muscle glycogen synthase activation in vivo in man is related to low fasting glycogen synthase phosphatase activity. J. Clin. Invest. 82:1503-1509.

16. Chiasson, J. L., M. R. Dietz, H. Shikama, M. Wootten, and J. H. Exton. 1980. Insulin regulation of skeletal muscle glycogen metabolism. Am. J. Physiol. 239:E69-E74

17. Chang, L. Y., and L. C. Huang. 1980. Effects of insulin treatment on the activities of phosphoprotein phosphatase and its inhibitors. Acta Endocrinol. 95:427-432.

18. Le Marchand-Brustel, Y., and P. Freychet. 1981. Regulation of glycogen synthase activity in the isolated mouse soleus muscle. Effect of insulin, epinephrine, glucose and anti-insulin receptor antibodies. Biochim. Biophys. Acto. 677:13-22.

19. Toth, B., M. Bollen, and W. Stalmans. 1988. Acute regulation of hepatic protein phosphatase by glucagon, insulin and glucose. J. Biol. Chem. 263:1406114066

20. Kida, Y., A. E. Puente, C. Bogardus, and D. M. Mott. 1990. Insulin resistance is associated with reduced fasting and insulin-stimulated glycogen synthase phosphatase activity in human skeletal muscle. J. Clin. Invest. 85:476-481.

21. Walkenbach, R. J., R. Hazen, and J. Larner. 1980. Hormonal regulation of glycogen synthase: insulin decreases protein kinase sensitivity to cyclic AMP. Biochim. Biophys. Acta. 629:421-430.

22. Okubo, M., C. Bogardus, S. Lillioja, and D. M. Mott. 1989. Fasting and insulin stimulated adenosine 3',5'-monophosphate dependent protein kinase from human muscle. J Clin. Endocrinol Metab. 69:798-803.

23. Walsh, D. A., and R. H. Cooper. 1979. The physiological regulation and function of cAMP-dependent protein kinases. In Biochemical Action of Hormones. G. Litwack, editor. Academic Press, NY. 6:1-75.

24. Cohen, P. 1978. The role of cyclic-AMP-dependent protein kinase in the regulation of glycogen metabolism in mammalian skeletal muscle. Curr. Top Cell. Regul. 14:117-196.

25. Mor, M. A., J. Vila, C. J. Ciudad, and J. J. Guinovart. 1981. Insulin inactivation of rat hepatocyte cyclic AMP-dependent protein kinase. FEBS (Fed Eur. Biol. Soc.) Lett. 136:131-134.

26. Oron, Y., G. Galasko, and J. Larner. 1980. Insulin action in intact mouse diaphragm. II. Inhibition of endogenous protein phosphorylation. Mol. Cell. Bio chem. 32:161-167.

27. National Diabetes Data Group. 1979. Classification and diagnosis of dia betes mellitus and other categories of glucose intolerance. Diabetes. 28:10391057.

28. Goldman, R, F, and E. R Buskirk 1961. A method for underwater weighing and the determination of body density. In Techniques for Measuring Body Composition. J. Brozek and A. Henschel, editors. National Academy of Sciences, National Research Council, Washington, DC. 78-89.

29. Guinovart, J. J., A. Salavert, J. Massague, C. J. Ciudad, E. Salsas, and E. Itarte. 1979. Glycogen synthase: a new activity ratio assay expressing a high sensitivity to the phosphorylation state. FEBS (Fed. Eur. Biol. Soc.) Lett. 106:284 288.

30. Thomas, J. A., K. K. Schlender, and J. Larner. 1968. A rapid filter paper assay for UDP glucose-glycogen glycosyltransferase, including an improved biosynthesis of UDP-14 C-glucose. Anal. Biochem. 25:486-499.

31. Maller, J. L., B. E. Kemp, and E. G. Krebs. 1978. In vivo phosphorylation of a synthetic peptide substrate of cyclic AMP-dependent protein kinase. Proc. Natl. Acad. Sci. USA. 75:248-251.

32. Roskoski, R. 1983. Assay of protein kinase. Methods Enzymol. 99:3-6.

33. Bollen, M., and W. Stalmans. 1988. Fluoride compounds inhibit the conversion of active type-1-protein phosphatase into the ATP $\mathrm{Mg}$-dependent form. Biochem. J. 255:327-333.

34. Mandarino, L. J., K. S. Wright, L. S. Verty, J. Nichols, J. M. Bell, O. G. Kolterman, and H. Beck-Nielsen. 1987. Effects of insulin infusion on human skeletal muscle pyruvate dehydrogenase, phosphofructokinase, and glycogen synthase. J. Clin. Invest. 80:655-663.
35. Yki-Järvinen, H., D. Mott, A. A. Young, K. Stone, and C. Bogardus. 1987. Regulation of glycogen synthase and phosphorylase activities by glucose and insulin in human skeletal muscle. J. Clin. Invest. 80:95-100.

36. Shulman, G. I., D. L. Rothman, T. Jue, P. Stein, R. A. DeFronzo, and R. G. Shulman. 1990. Quantitation of muscle glycogen synthesis in normal subjects and subjects with non-insulin-dependent diabetes by ${ }^{13} \mathrm{C}$-nuclear magnetic resonance spectroscopy. $N$. Engl J. Med 322:223-228.

37. Young, A. A., C. Bogardus, D. Wolfe-Lopez, and D. M. Mott. 1988. Muscle glycogen synthesis and disposition of infused glucose in humans with reduced rates of insulin-mediated carbohydrate storage. Diabetes. 37:303-307.

38. Embi, N., P. J. Parker, and P. Cohen. 1981. A reinvestigation of the phosphorylation of rabbit skeletal-muscle glycogen synthase by cyclic-AMP-dependent protein kinase. Identification of the third site of phosphorylation as serine-7. Eur. J. Biochem. 115:405-413.

39. Sheorain, V. S., J. D. Corbin, and T. R. Soderling. 1985. Phosphorylation of sites 3 and 4 in rabbit skeletal muscle glycogen synthase by cAMP-dependent protein kinase. J. Biol. Chem. 260:1567-1572.

40. Huang, F. L., and W. H. Glinsmann. 1976. Separation and characterization of two phosphorylase phosphatase inhibitors from rabbit skeletal muscle. Eur. J. Biochem. 70:419-426.

41. Foulkes, J. G., P. Cohen, S. J. Strada, W. V. Everson, and L. S. Jefferson. 1982. Antagonistic effects of insulin and beta-adrenergic agonists on the activity of protein phosphatase inhibitor-1 in skeletal muscle of the perfused rat hemicorpus. J. Biol. Chem. 257:12493-12496.

42. Hiraga, A., and P. Cohen. 1986. Phosphorylation of the glycogen-binding subunit of protein phosphatase-1G by cyclic-AMP-dependent protein kinase promotes translocation of the phosphatase from glycogen to cytosol in rabbit skeletal muscle. Eur. J. Biochem. 161:763-769.

43. Gottschalk, W. K., and L. Jarett. 1985. Intracellular mediators of insulin action. Diabetes Metab. Rev 1:229-259.

44. Cheng, K., and J. Larner. 1985. Intracellular mediators of insulin action. Annu. Rev. Physiol. 47:405-424.

45. Chasiotis, D., and E. Hultman. 1985. The effect of adrenalin infusion on the regulation of glycogenolysis in human muscle during isometric contraction. Acta Physiol. Scand. 123:55-60.

46. Walaas, O., E. Walaas, and O. Gronnerod. 1973. Hormonal regulation of cyclic-AMP-dependent protein kinase of rat diaphragm by epinephrine and insulin. Eur. J. Biochem. 40:465-477.

47. Corbin, J. D., S. L. Keely, and C. R. Parks. 1975. The distribution and dissociation of cyclic adenosine $3^{\prime}: 5^{\prime}$ monophosphate-dependent protein kinases in adipose, cardiac and other tissues. J. Biol. Chem. 250:218-225.

48. Corbin, J. D., T. R. Soderling, and C. R. Parks. 1973. Regulation of adenosine 3',5'-monophosphate-dependent protein kinase. J. Biol. Chem. 248:1813-1821.

49. Cherrington, A. D., F. D. Assimacopoulos, S. C. Harper, J. D. Corbin C. R. Parks, and J. H. Exton. 1976. Studies on the $\alpha$-adrenergic activation of hepatic glucose output. J. Biol. Chem. 251:5209-5218.

50. Palmer, W. K., J. M. McPherson, and D. A. Walsh. 1980. Critical controls in the evaluation of cAMP-dependent protein kinase activity ratio as indices of hormonal control. J. Biol. Chem. 255:2663-2666.

51. Ciudad, C. J., J. Vila, M. A. Mor, and J. J. Guinovart. 1987. Effects of glucagon and insulin on the cyclic AMP binding capacity of hepatocyte cyclic AMP-dependent protein kinase. Mol. Cell. Biochem. 73:37-44.

52. Gabby, R. A., and H. A. Lardy. 1987. Insulin inhibition of hepatic cAMPdependent protein kinase: decreased affinity of protein kinase for cAMP and possible differential regulation of intrachain sites 1 and 2. Proc. Natl. Acad. Sci. USA. 84:2218-2222.

53. Yang, S., L. Ho, and T. Fung. 1988. Insulin induces activation and transocation of protein kinase FA (a multifunctional protein phosphatase activation) in human platelet. Biochem. Biophys. Res. Commun. 151:61-69.

54. Hemmings, B. A., D. Yellowlees, J. C. Kernohan, and P. Cohen. 1981. Purification of glycogen synthase kinase 3 from rabbit skeletal muscle. Eur. $J$. Biochem. 119:443-451.

55. Vandenheede, J. R., S. Yang W. Merlevede, S. Jurgensen, and P. B. Chock. 1985. Kinase-FA-mediated regulation of rabbit skeletal muscle protein phosphatase. J. Biol. Chem. 260:10512-10516.

56. Larner, J., G. Galasko, K. Cheng, A. A. Depaoli-Roach, L. Huang P. Deggy, and J. Kellogg. 1979. Generation by insulin of a chemical mediator that controls protein phosphorylation and dephosphorylation. Science (Wash. DC). 206:1408-1410.

57. Cheng, K., M. Thompson, J. Craig, C. Schwartz, E. Locher, and J. Larner. 1984. Cell membrane signals in the mechanism of insulin action. Ann. Clin. Lab. Sci. 14:78-89.

58. Jarett, L., F. L. Kiechle, J. C. Parker, and S. L. Macauley. 1983. The chemical mediators of insulin action: possible targets for postreceptor defects. Am. J. Med. 74:31-37.

59. Thompson, M. P., J. Larner, and D. L. Kilpatrick. 1984. Purification and partial characterization of a putative mediator of insulin action on cyclic AMPdependent protein kinase. Mol. Cell. Biochem. 62:67-75. 